\title{
The Value of Cerebrospinal Fluid Polymerase Chain Reaction Test in the Diagnosis of Enteroviral Meningitis in Children
}

\section{Çocuklarda Enteroviral Menenjit Tanısında Beyin omurilik Sıvısı Polimeraz Zincir Reaksiyonu Testinin Önemi}

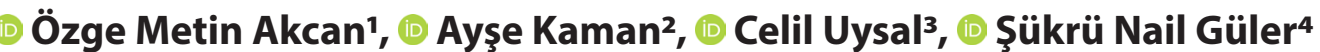 \\ 'Necmettin Erbakan Univercity School of Medicine, Division of Pediatric Infectious Diseases, Konya, Turkey \\ 2Dr. Sami Ulus Maternity and Children's Research and Training Hospital, Division of Pediatric Infectious Diseases, Ankara, Turkey \\ ${ }^{3}$ Konya Training and Research Hospital, Department of Pediatrics, Konya, Turkey \\ ${ }^{4} \mathrm{Necmettin}$ Erbakan Univercity School of Medicine, Division of Pediatric Immunology and Allergy, Konya, Turkey
}

\begin{abstract}
Background: Non-polio enteroviruses (EVs) are emerged as the most common pathogens of aseptic meningitis in children. In this study we aimed to evaluate clinical, laboratory, cerebrospinal fluid (CSF) findings and the usefulness of CSF EV polymerase chain reaction (PCR) on management of pediatric patients diagnosed as EV aseptic meningitis.

Material and Method: This study included the pediatric patients with aseptic meningitis between January 2014 and January 2016.

Results: A total of 23 patients (69.5\% boys) diagnosed with EV aseptic meningitis with a median age of 57 months old (range; 1-168 months) were included. The most common months of the patients' admission to hospital were July and May. The most common clinical complaints were womiting (77.2\%), fever (73.9\%), headache (59\%), neck stiffness (36.3\%), seizure $(22.7 \%)$ and altered consciousness (22.7\%). CSF pleocytosis was observed in 16 (69.5\%) patients and the median CSF white blood cell (WBC) count was 50 cells $/ \mathrm{mm} 3$ ranged from 0 to 500 cells $/ \mathrm{mm} 3$. It was found that, CSF cell count was significantly increased with age $(p=0.02)$, whereas acute phase reactant levels and CSF biochemical components were statistically similar according to age ( $p>0.05)$. Median duration for hospitalization was 6 days (range: 1-28 days). Eight patients (34.7\%) did not receive any antibiotics.
\end{abstract}

Conclusion: Absence of pleocytosis may be a diagnostic challange in very young infants with aseptic meningitis and CSF cell count significantly increases with age. By using rapid EV-PCR assays in the initial diagnosis of aseptic meningitis, the unnecessary usage of antibiotics in viral meningitis can be reduced and also the duration of hospitalization can be shortened.

Keywords: Aseptic meningitis, children, enteroviruses, polymerase chain reaction
Öz

Amaç: Non-polio enterovirüsler (EV), çocuklarda aseptik menenjitin en sık nedeni olarak ortaya çıkmaktadır. Bu çalışmada EV aseptik menenjit tanısı konulan pediyatrik hastaların klinik, laboratuvar, beyin omurilik SIVISI (BOS) bulguları ve BOS EV polimeraz zincir reaksiyonunun (PZR) hastaların yönetiminde yararlıı̆ını değerlendirmeyi amaçladık.

Gereç ve Yöntem: Bu çalışmaya Ocak 2014 ile Ocak 2016 arasında aseptik menenjit tanısı konulan pediyatrik hastalar dahil edildi.

Bulgular: Ortanca yaşı 57 ay (1-168 ay) olan EV aseptik menenjit tanısı alan toplam 23 hasta (\% 69.5 erkek) çalışmaya dahil edildi. Hastaların hastaneye başvurusunun en fazla olduğu aylar Temmuz ve Mayıs aylarıydı. En sık klinik bulgular; kusma $(\% 77,2)$, ateş $(\% 73,9)$, baş ağrısı (\%59), ense sertliği $(\% 36,3)$, nöbet $(\% 22,7)$ ve bilinç değişikliği $(\% 22,7)$ idi. On altı hastada $(\% 69,5)$ BOS pleositozu gözlendi ve ortanca BOS beyaz kan hücre sayısı (WBC) 50 hücre / mm3 olup, 0 ile 500 hücre / mm3 arasında değişmektedir. BOS hücre sayısının yaşla birlikte anlamlı derecede arttığı ( $p=0.02)$, akut faz reaktan düzeyleri ve BOS biyokimyasal değerlerinin yaşa göre istatistiksel olarak benzer olduğu bulundu ( $p>0.05$ ). Hastanede yatış süresi ortanca 6 gündü (aralık: 1-28 gün). Sekiz hastaya $(\% 34,7)$ antibiyotik verilmedi.

Sonuç: Aseptik menenjitli çok küçük bebeklerde pleositoz olmaması tanısal bir güçlük olabilir ve BOS hücre sayısı yaşla birlikte önemli ölçüde artmaktadır. Aseptik menenjitin tanısında hızlı EV-PCR analizleri kullanılarak viral menenjitte gereksiz antibiyotik kullanımı azaltılabilir ve ayrıca hastanede yatış süresi kısaltılabilir

Anahtar Kelimeler: Aseptik menenjit, çocuklar, enterovirüs, polimeraz zincir reaksiyonu

Corresponding (IIletişim): Ayşe Kaman, Dr. Sami Ulus Maternity and Children's Research and Training Hospital Babür street Number:44 (06080) Altındağ Ankara, Turkey

E-mail (E-posta): ayse092003@yahoo.com

Received (Geliş Tarihi): 21.06.2020 Accepted (Kabul Tarihi): 24.06.2020 


\section{INTRODUCTION}

Acute aseptic meningitis is a term of an acute central nervous system (CNS) syndrome which defines a self-limited meningitis of non-bacterial etiology. ${ }^{[1]}$ Although aseptic meningitis is more common than bacterial meningitis in childhood, the total annual incidence of disease is unknown because the disease is not reportable in many developed countries..$^{[1,2]}$ The Centers for Disease Control and Prevention (CDC) reported that the incidence of aseptic meningitis reached from 1.5-4 per 100.000 people over a 10 years period. It is known that the highest number of cases occur in infants, toddlers, and children under 4 years of age. ${ }^{[1]}$ After the recommendation of routine mumps and polio vaccines in childhood routine vaccination schedules in developed countries, the nonpolio enteroviruses (EVs) are emerged as the principal responsible pathogens of aseptic meningitis. ${ }^{[1,3,4]}$ The clinical presentations of enteroviral aseptic meningitis in children is various and distinguish from bacterial meningits is difficult according to clinical signs espceially in infants aged less than 3 months. ${ }^{[3,4]}$ Although aseptic meningitis is frequently reported to be characterized by a cerebrospinalfluid (CSF) mononuclear cell dominant pleocytosis after the early phase of disease [in the first 24 hour of illness polymorphonuclear (PMN) cell dominant pleosytosis is prevalent], the presence of CSF pleocytosis and predominant cells are also variable and agedependent, making it a diagnostic challenge. ${ }^{[3,4]}$ Also it was reported that the PMN predominance may not be limited to the first $24 \mathrm{~h}$ of illness that lead to difficulties to disciriminate between aseptic and bacterial meningitis. The diagnosis of EVs infection by the isolation of virus in cell cultures is limited due to the relatively low sensitivity (65-75\%) and also expensive costs. The rapid techniques like nucleic acid amplification by reverse transcriptase polymerase chain reaction (RT-PCR) provide more accurate, fast and less expensive results with strong sensitivity and specifity. ${ }^{[4]}$ In this study we aimed to present clinical, laboratory and CSF findings of pediatric patients diagnosed as enteroviral aseptic meningitis. We also aimed to evaluate the usefulness of CSF EV PCR to investigate the responsible pathogen and to describe the effect on management of acute meningitis in children.

\section{MATERIAL AND METHOD}

This study retrospectively evaluated the results of patients with a diagnosis of enteroviral meningitis between January 2014 and January 2016. Specimens were tested by using multiplex real- time PCR assay (Fast track diagnosis NEURO9 and Fast track diagnosis Bacterial meningitidis real time PCR kit) for Adenovirus (AdV), Cytomegalovirus (CMV), EV (Polioviruses, Coxackieviruses, Echoviruses, and other enteroviruses), Ebstein- Barr virus (EBV), Herpes simplex virus 1 and 2, Human Herpes virus 6 and 7, Varicella Zoster virus (VZV), Human Parechoviruses and Parvovirus B19, Hemophilus influenzae, Streptococcus pneumoniae or Neisseria meningitidis. Data regarding age, sex, presence of comorbid disease, admission month and season, illness time before admission, clinical findings, acute phase reactant levels, CSF biochemical component levels, CSF cell numbers and distribution and blood culture and CSF culture results, duration of hospitalization, treatment options and outcomes were recorded.

\section{RESULTS}

A total number of 176 specimen were evaluated during the study period and only 23 patients [ 16 boys (69.5\%), 7 girls (30.5\%)] diagnosed with EV aseptic meningitis were included in the study. Median age of patients were 57 months old (range; 1-168 months). Two patients (8.6\%) were less than 30 days old, four patients (17.3\%) were aged between 30 days and $<1$ year and remaining 17 patients were aged $\geq 2$ years. The most common months of the patients' admission to hospital setting July $(n=9)$ and May $(n=7)$ followed by June $(n=2)$, January $(n=2)$, March $(n=1)$, August $(n=1)$ and September $(n=1)$, respectively. The most common clinical complaints on admission were womiting (77.2\%), fever (73.9\%), headache (59\%), neck stiffness $(36.3 \%)$, seizure $(22.7 \%)$ and altered consciousness (22.7\%). Six patients [(26.1\%), two patients aged $<1$ month old, two patients aged 1 month to 1 year old, two patients aged $>2$ years] had no fever on hospital admission. It was known that one patient (4.3\%) was following with a diagnosis of primary immune deficiency by the pediatric immunology department.

Acute phase reactants were as follows; median white blood cell count (WBC) was $15100 / \mathrm{mm}^{3}$ (minimum:6310/mm maximum: $\left.22390 / \mathrm{mm}^{3}\right)$, median absolute neutrophil percent was 79\% (min: $8 \%$, max: $90 \%$ ), median C-reactive protein (CRP) was $6 \mathrm{mg} / \mathrm{dL}$ (min:3mg/dL, max:186 mg/dL), median erythrocyte sedimentaton rate (ESR) was $11 \mathrm{~mm} / \mathrm{h}$ (min: 2 $\mathrm{mm} / \mathrm{h}$, max: $44 \mathrm{~mm} / \mathrm{h}$ ). Acute phase reactant levels were statistically similar according to age distribution ( $p>0.05$ ).

\begin{tabular}{lccc}
\hline Table 1. Acute phase reactants of patients & & \\
\hline Parameter & Median & Minimum & Maksimum \\
Total leukocyte $\left(/ \mathrm{mm}^{3}\right)$ & 15100 & 6310 & 22390 \\
Absolut neutrophil count $(\%)$ & 79 & 8 & 90 \\
CRP $(\mathrm{mg} / \mathrm{dL})$ & 6 & 3 & 186 \\
ESR $(\mathrm{mm} / \mathrm{h})$ & 11 & 2 & 44
\end{tabular}

The median CSF WBC count was 50 cells $/ \mathrm{mm}^{3}$ ranged from 0 to 500 cells $/ \mathrm{mm}^{3}$. In 12 patients (52.1\%) PMN cell predominance was detected. Six of these patients (50\%) underwent control lumbar puncture 24 hours after admission and a shift to mononuclear cell dominance was observed. CSF pleocytosis was observed in 16 (69.5\%) patients. Two patients aged less than $\leq 30$ days, two patients aged 1 month to 6 months and three patients aged $\geq 1$ year had no CSF pleocytosis. Theese 3 patients aged $\geq 1$ year had undergone lumbar puncture within early phase of their clinical symptoms (two patients 
within 24 hours of clinical complaints and one patient within 48 hours). It was found that, CSF cell count was significantly increased with age $(p=0.02)$. The median CSF total protein and glucose values were $32 \mathrm{mg} / \mathrm{d} \mathrm{L}$ (range: 14-133 mg/dL) and $67 \mathrm{mg} / \mathrm{dL}$ (range: $48-89 \mathrm{mg} / \mathrm{dL}$ ) respectively and these CSF biochemical components were not reveal statistically significant difference by age ( $p>0.05$ ) (Table 2). Blood cultures were performed in 14 (60.8\%) patients on admission and none of them yielded any microorganism. All of the patients (100\%) were hospitalized with a median duration for hospitalization of 6 days (range: 1-28 days). Duration of hospitalization was statistically similar according to age distribution $(p>0.05)$. One patient with the diagnosis of primary immune deficiency had severe illness. Eleven patients (47.8\%) were treated with 3rd generation cephalosporin plus vancomycin, 2 patients $(8.7 \%)$ were treated with ampicillin plus 3rd generation cephalosporin and 2 patients (8.7\%) were treated with 3rd generation cephalosporin alone, while 8 patients $(34.7 \%)$ did not receive any antibiotics. Five of the patients who had not been commenced antibiotics (62.5\%) had no pleocytosis in CSF sample. Two patients (8.7\%) were reffered another hospital and remaining 21 patients $(91.3 \%)$ recovered well acutely with no major acute sequelae. All commenced antibiotics were stopped once CSF EV PCR resulted positive.

\begin{tabular}{|c|c|c|c|}
\hline \multirow{2}{*}{ Variable* } & \multicolumn{2}{|c|}{ Age } & \multirow{2}{*}{$\mathbf{p}$} \\
\hline & $<1$ year & $\geq 1$ year & \\
\hline CSF white cell count $\left(/ \mathrm{mm}^{3}\right)$ & $0(0-150)$ & $100(0-500)$ & 0.02 \\
\hline CSF protein (mg/dl) & $28(17-133)$ & $32(14-76)$ & 0,88 \\
\hline CSF glucose (mg/dl) & $68(57-78)$ & $64(48-89)$ & 0,61 \\
\hline $\mathrm{CRP}(\mathrm{mg} / \mathrm{dL})$ & $3(3-186)$ & $8(3-126)$ & 0,35 \\
\hline Total leukocyte $\left(/ \mathrm{mm}^{3}\right)$ & $\begin{array}{c}15200 \\
(6300-20900)\end{array}$ & $\begin{array}{c}14800 \\
(8700-22400)\end{array}$ & 0,73 \\
\hline Duration of hospitalization & $7(1-28)$ & $5(1-10)$ & 0,48 \\
\hline
\end{tabular}

\section{DISCUSSION}

Aseptic meningitis is the most common cause of childhood meningitis with an incidence of 1.5-4 per 100.000 people over 10 years period, which is about 20 times greater than bacterial meningitis. ${ }^{[1,2]}$ Although conventional culture methods are the gold standard method for determination of the pathogen in the CNS infection, currently exisiting identification procedures for viruses, including viral cultures and serologic tests have limited practical use because of low sensitivity and poor rapid dignostic effects. ${ }^{[4,5]}$ Nucleic acid amplification tests have been used more frequently worldwide in the diagnosis of meningitis. ${ }^{[2,5]}$ The reported rates in several studies for determination exact viral pathogen of aseptic meningitis are varying according to different reasons including geographic features, age, used PCR method. ${ }^{[6]}$ It is known that approximately in $50 \%$ of patients with aseptic meningitis, the pathogen can be documented.
[2] In a study from Texas, including a total 509 patients (404 adults and 105 children), it was reported that in $81 \%$ percent of patients the etiologies could not been documented. It was found that children were less likely to have an unknown infectious etiology (60.9\% vs $85.6 \%$ ). In this study 78 children had underwent CSF PCR for EV, and 40 of them (51.3\%) had positive results for $\mathrm{EV}$. The authors postulated that the reason of low yield in determination of viral etiology in this study, could be explained by underutilization of PCR for the most common viruses and for arboviral serologies in real-lifetime practice. ${ }^{[6]}$ It is known that EV is the most common responsible pathogen in childhood aseptic meningitis regardless of age. $[2,3,6]$ It was reported that, more than 10000 patients with aseptic meningitis caused by EV are reported annually to the CDC. ${ }^{[7]}$ Whereas EVs associated diseases may occur throughout the year in most geographic regions, much higher rates of disease present in summer anf fall in temperate climates. ${ }^{[1,6,7]}$ In this study predominance of EV aseptic meningitis in months May to August was in agreement with those previous reports.

Clinical presentations of EV aseptic meningitis may vary by age, presence of comorbid disease, gestation week for infants. ${ }^{[2,4,8]}$ The severity of illness can vary in a wide range, from mild self-limited illness with fever, irritability, meningeal complaints consisted of headache, neck stiffness, nausea to more severe illness with convulsions or altered consciousness level and death. ${ }^{[4]}$ In a study involving adults and children, $45.8 \%$ of patients were male $(42.3 \%$ of adults and $59 \%$ of children) and it was reported that children were less likely to be presented with meningeal complaints (e.g., headache, stiff neck, nausea, photophobia) than adults. Furthermore children were usually submitted to hospital with a nonspescific febrile illness consisted with fever, respiratory symptoms, and leukocytosis in this study. ${ }^{[6]}$ In an another study, including a total 172 patients (60\% male predominance, 65 patients were $<3$ years-old, 58 patients were 3-18 years-old and 49 patients were $>18$ years), it was reported that, admission to hospital with meningeal complaints (triad of; fever, headache, and neck stiffness), which was present in $46.5 \%$ of total patients and only in $6.1 \%$ of children under 3 years old, was more common in adults. A total of $10 \%$ of patients had severe forms of disase and $14.5 \%$ of patients were transferred to intensive care unit (ICU) due to complications including encephalitis, hypotension or acute respiratory distress syndrome (ARDS). Most of the patients who need care in ICU were infants (23 patients were $<3$ years-old) and it was statistically signficant. Extra-neurological symptoms like non-specific skin rash were also more commonly found in pediatric patients ( $18.1 \%$ vs. $2 \%$ ) (8). In the neonatal period (<90 days), EVs are one of the main common cause of nonspecific febrile illness, accounting for approximately $25-60 \%$ of febrile illness related hospitalization during year around without seasonal dominance. ${ }^{[2,9]}$ Enteroviral aseptic meningitis, often causes a benign illness which does not result in serious sequela in newborns, unless 
presented with multisystem involvement and does not occur in a premature infant. ${ }^{[2]}$ The present study which included only patients aged $<18$ years revealed a male predominance. Only two patients were admitted to hospital during the neonatal period and almost $75 \%$ of patients were aged $>2$ years. While neither of the newborns had fever on admission.

The certain diagnosis of EV meningitis in very young infants remains a challange, because clinical presentations in young infants are very non-specific and presence of CSF pleocytosis and PMN cells predominance in CSF do not allow to definitely differentiate between viral and bacterial etiology. ${ }^{[2]}$ However CSF pleocytosis may be absent even in patients with proven EV meningitis especially in infants younger than 90 days. It was estimated that, about $30 \%$ of infants younger than 90 days and $40-77 \%$ of neonates did not have pleocytosis. ${ }^{[9,10]}$ A study conducted in an urban tertiary care childrens hospital, a total of 154 very young infants who had a positive CSF EV PCR test result were included. Ninety-three (60.4\%) of paitents were female and the median age was 36 days (IQR, 19-52 days). It was found that CSF pleocytosis was present in 109 (71\%) of patients and CSF pleocytosis statistically increased with age; CSF pleocytosis was present in 59\%, $74 \%$ and $90 \%$ of infants aged 0 to 28,29 to 56 , and 57 to 90 days, respectively. This study also revealed that age and peripheral WBC count were independently associated with CSF pleocytosis. The authors postulated that this differences were as a result of the decreased ability of younger infants to mount a potent inflammatory response to EV infection. ${ }^{[10]}$ In an another study conducted from Canada, it was documented that pleocytosis was absent in $22.3 \%$ of children $<30$ days of age with proven EV meningitis. ${ }^{[1]}$ In a descriptive study, including 58 patients ( 35 neonates and 23 children) during six months (March to Seprember), it was revealed that EV PCR was positive in $37.1 \%$ and $34.7 \%$ of the neonates and children, respectively. Pleocytosis in CSF samples was positive in $51.1 \%$ of overall patients whereas in $23 \%$ and $75 \%$ of EV PCR positive neonates and children, respectively. Furthermore PMN dominance in CSF samples was seen in $50 \%$ and $33 \%$ of EV positive neonates and children, respectively. Patients with pure enteroviral meningitis were hospitalized for a mean duration of 1.6 days (1-4 days). The authors concluded that, both normal CSF findings and PMN dominancy of CSF was common in neonates and children with EV meningitis (2). In a study from Singapore, a total of 206 children aged younger than 16 years with positive CSF EV PCR, were evalutaed retrospectively. Pleocytosis in CSF was observed in $66 \%$ of children aged $\leq 90$ days, $75 \%$ of aged 90 days- 1 year and 94 $\%$ of $\geq 3$ years. It was also revealed that early lumbar puncture within 48 hours of symptoms and absence of CSF pleocytosis was also correlated. Protein and sugar ratios of CSF were not discriminatory. All of the patients except one patient received intravenous antibiotics for a median of 2 days. The authors conluded that CSF analysis including EV PCR could avoid unnecessary antibiotic therapy. ${ }^{[3]}$ In the present study all of the neonates had no CSF pleocytosis. Three patients $>1$ year of age (3/17) who undergoing lumbar puncture within early phase of symptoms had no pleocytosis. Although it was not statistically significant, the rate of CSF pleocytosis positiviy was correlated with age. But CSF biochemical components were not discriminatory. Median duration of hospitalization were a little longer than the previously reported literature.

Although aseptic meningitis is more common than bacterial in all ages during childhood, the majority of neonates and young infants $<90$ days presenting with fever, even if children are not seriously ill, are frequently hospitalized and emprically treated with antibiotics for potential sepsis while waiting results of culture and/or rapid viral diagnostic tools. These infants often do not have classic signs of aseptic meningitis that may be found in older children and adults. ${ }^{[2,9,12]}$ By rapid detection of EVs in CSF by RT PCR in all cases of aseptic meningitis, the duration of hospitalization can be shortened, the unnecessary usage of antibiotics, the cost of disease and also healthcare associated infections may be reduced. ${ }^{[2,9]}$ In a study aimed to investigate the impact of a rapid CSF EV PCR with time to result of 3 to 6 hours on hospital duration time and duration of antimicrobial treatment in children younger than 3 months of age with aseptic meningitis, a total of 128 children [58 patients before and 70 patients (EV positive in 42 patients, EV negative in 28 patients) after the introduction of rapid CSF EV PCR testing] were inclueded. It was revealed that duration of antimicrobial treatment was significantly shortened in EV positive compared to both EV negative and untested patients. Hospitalization duration was significantly shortened in EV positive compared to EV negative patients (median 3 days vs 4 days), while an overall reduction was not observed between tested and untested group patients. ${ }^{[9]}$ In an another study evaluating the impact of a positive diagnosis using EV PCR, clinical datas of patients were compared between whose positive EV-PCR results were obtained within $24 \mathrm{hr}(\mathrm{n}=32)$ and those whose results were obtained after 24 hours ( $n=14)$. It was documented that duration of antibiotic treatment (difference: 2.3 days) was reduced between two groups, whereas no statistical difference was observed in the length of hospital stay. The authors underlined that the molecular diagnosis of an illness that producing of concern positively affects management and they concluded that, EVPCR assay should be performed daily in hospital practice as the part of initial diagnosis and management of meningitis. ${ }^{[12]}$ In this study $34.7 \%$ of patients did not receive any antibiotics and all coomenced antibiotics were stopped safely once CSF enterovirus PCR resulted positive. In this study rapid CSF EV PCR testing was thought to provided a reduction in antimicrobial prescription rate and total duration of antimicrobial use. 


\section{CONCLUSION}

In conclusion, EVs are an important cause of aseptic meningitis especially during summer to fall. Absence of pleocytosis may be a diagnostic challange in very young infants with aseptic meningitis and CSF cell count significantly increases with age. Therefore CSF EV PCR testing should be considered in young febrile infants as a part of septic work up evaluated by lumbar puncture even in the absence of CSF pleocytosis. By using of rapid EV-PCR assays in the initial diagnosis of aseptic meningitis, the unnecessary usage of antibiotics in viral meningitis can be reduced and also the duration of hospitalization can be shortened.

\section{ETHICAL DECLARATIONS}

Ethics Comittee Approval: According to the Regulation on Clinical Researches published in the official newspaper with the number 28617 dated 3 November 2015, the ethics committee approval was not obtained in accordance with the article "Retrospective studies are outside the scope of the regulation (article 2- (2))". This study was prepared in accordance with the Law on Protection of Personal Data, by anonymizing patient data and in accordance with the 2013 Brazil revision of the Helsinki Declaration and guidelines for Good Clinical Practice.

Informed Consent: Because the study was designed retrospectively, no written informed consent form was obtained from patients.

Status of Peer-review: Externally peer-reviewed.

Conflict of Interest Statement: The authors have no conflicts of interest to declare.

Financial Disclosure: The authors declared that this study has received no financial support.

Author Contributions: All of the authors declare that they have all participated in the design, execution, and analysis of the paper, and that they have approved the final version.

Note: This study data was presented as oral presentation at "Turkish National Association of Pediatrics 'a day of a Pediatrician' Education Meeting" in 2018.

\section{REFERENCES}

1. Romero JR. Aseptic and Viral Meningitis. In: Long SS, Ficher M, Prober CG, editors. Principles and practice of pediatric infectious diseases. 5th ed. Philadelphia, PA: Elsevier. 2018:p292-7.

2. Ghabouli Shahroodi MJ, Ghazvini K, Sadeghi R, Sasan MS. Enteroviral Meningitisin Neonates and Children of Mashhad, Iran. Jundishapur J Microbiol 2016;9(5):e19955.

3. Tan NW, Lee EY, Khoo GM, Tee NW, Krishnamoorthy S, Choong CT. Cerebrospinal fluid white cell count: discriminatory or otherwise for enteroviral meningitis in infants and young children? J Neurovirol 2016;22(2):213-7.

4. Shaker OG, Abdelhamid N. Detection of enteroviruses in pediatric patients with aseptic meningitis. Clin Neurol Neurosurg 2015;129:67-71
5. Kahraman $\mathrm{H}$, Tünger $\mathrm{A}$, Senol Ş, et al. [Investigation of bacterial and viral etiology in community acquired central nervous system infections with molecular methods]. Mikrobiyol Bul 2017;51(3):277-85.

6. Shukla B, Aguilera EA, Salazar L, Wootton SH, Kaewpoowat Q, Hasbun R. Aseptic meningitis in adults and children: diagnostic and management challenges. J Clin Virol 2017;94:110-4.

7. Zakhour R, Aguilera E, Hasbun R, Wootton SH. Risk classification for enteroviral Infection in children with meningitis and negative gram stain. Pediatr Emerg Care 2018;34(11):791-6.

8. Vareil M, Wille $H$, Kassab $S$, et al. Clinical and biological features of enteroviral meningitis among adults and children and factors associated with severity and length of stay. J Clin Virol 2018;104:56-60.

9. Paioni P, Barbey F, Relly C, Meyer Sauteur P, Berger C. Impact of rapid enterovirus polymerase chain reaction testing on management of febrile young infants $<90$ days of age with aseptic meningitis. BMC Pediatr 2020;20(1):166.

10. Seiden JA, Zorc JJ, Hodinka RL, Shah SS. Lack of cerebrospinal fluid pleocytosis in young infants with enterovirus infections of the central nervous system. Pediatr Emerg Care 2010;26(2):77-81.

11. Lee BE, Chawla R, Langley JM, et al. Paediatric Investigators Collaborative Network on Infections in Canada (PICNIC) study of aseptic meningitis. BMC Infect Dis 2006;6:68.

12. Archimbaud C, Chambon M, Bailly JL, et al. Impact of rapid enterovirus molecular diagnosis on the management of infants, children, and adults with aseptic meningitis. J Med Virol 2009;81(1):42-8. 